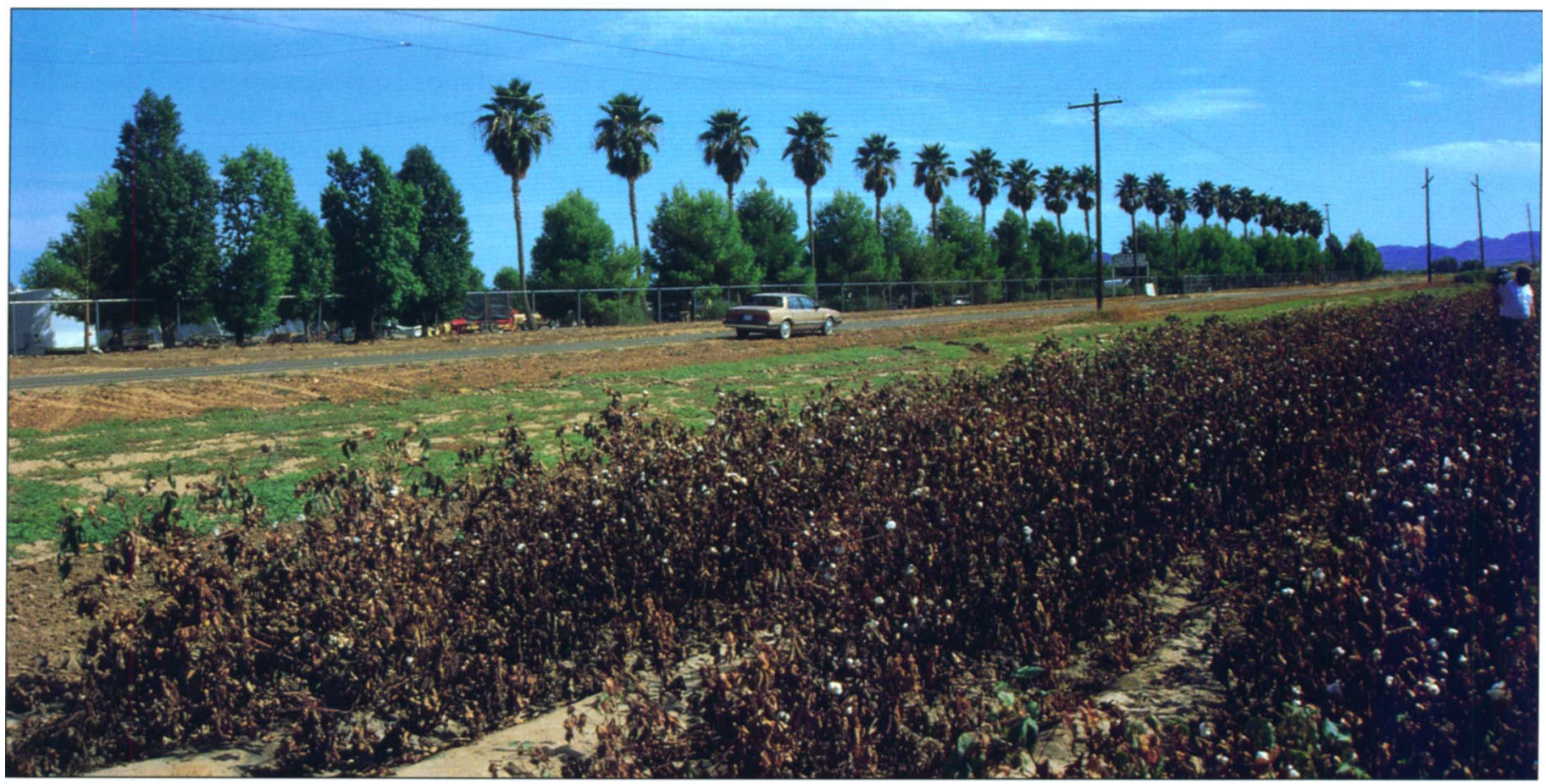

In 1981, high densities of sweetpotato whiteflies feeding on Imperial Valley cotton killed entire fields and contaminated cotton lint with honeydew. Subsequently a more destructive strain of whitefly, the silverleaf whitefly, has supplanted the sweetpotato whitefly.

\section{Persistent silverleaf whitefly exploits desert crop systems}

Nick C. Toscano \ Steve J. Castle Ј Thomas J. Henneberry Nilima Prabhaker Castle whitefly has cost more $\$ 2$ billion in crop loss and damage, and pest control.

The silverleaf whitefly is exceptional in its ability to colonize a great variety of crops, weeds and ornamentals. Southern California's diverse crops, high temperatures, and low rainfall help sustain whitefly populations at high levels, even during the winter months. The level of infestation of crops attained by silverleaf whitefly populations is driven by the insect's biological traits, the crops grown and the inadequacy of pest controls.
The past 15 to 20 years have seen the transformation of whiteflies from generally minor pests of field and greenhouse crops into major pests of various agricultural and horticultural plant systems. In particular, Bemisia tabaci Genn., the sweetpotato whitefly, and the recently described silverleaf whitefly, B. argentifolii Bell. \& Perr., have become the predominant pest species throughout many subtropical and tropical zones of the world.

Prior to the 1980s, few sweetpotato whitefly outbreaks had been recorded even though this species had long been resident in various agricultural regions throughout the southern United States. In 1981, a serious outbreak of sweetpotato whitefly occurred in the Imperial Valley of California. Populations grew to enormous densities on cotton, leading to direct feeding damage and contamination of cotton lint with honeydew. Heavy dispersal out of declining cotton in the fall months led to epidemics of lettuce infectious yellows virus in both lettuce and melon fields (Blua et al. 1994). The 


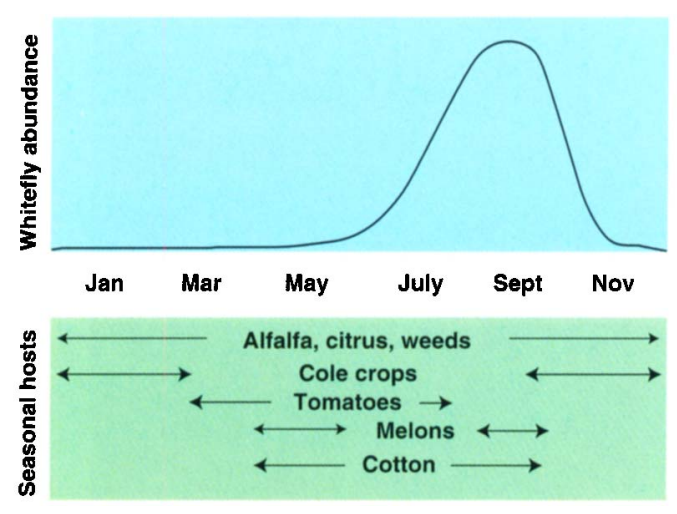

Fig. 1. Population growth of the silverleaf whitefly and the seasonal occurrence of major host crops in California.

whitefly spreads the virus. In subsequent years, sweetpotato whitefly continued to erupt into moderate to heavy population densities despite increasingly aggressive management tactics, such as crop destruction after harvest, short season cotton and multiple insecticide applications.

Whiteflies remained as a mostly occasional pest outside of the southwestern United States until 1986, when they infested crops in other parts of the country. In Florida, there were widespread outbreaks of viruslike symptoms in squash as well as whitefly infestations of poinsettia greenhouses, neither of which had ever been reported before. Additional occurrences of these phenomena began to be reported in other states, and soon scientists called this variant whitefly "strain B" to differentiate it from the whitefly that already infested the Imperial Valley, which they called "strain A." Strain A was found primarily on cotton and little, if anything, else except for weeds in the Malvaceae family. During the late 1980s, strain B heavily infested several crops in Florida and also was reported for the first time in California and Arizona, primarily in greenhouse ornamental crops.

It was not until the benchmark year of 1991 - the first worst year - that the full destructive potential of whiteflies became apparent in the Imperial Valley. Compared to strain A, strain B colonizes many vegetable and field crops grown in California, Arizona and Mexico (Brown 1994, Perring et al. 1991). B strain is found on alfalfa, cole crops and herbaceous plants that strain A isn't found on. In 1991 the strain B whitefly population built up on a succession of crops in the Imperial and Palo Verde Valleys, overwhelming pest-control efforts and resulting in widespread crop damage (Castle et al. 1996).

Since 1991, whitefly populations have remained at extremely high levels in the southwestern United States, necessitating intensive insecticide use to protect crops. Texas and Florida continue to experience moderate whitefly pressure infestations, other southern states such as Georgia and Mississippi have experienced whitefly problems in agricultural systems such as greenhouses, cotton and vegetables. Many northern states producing greenhouse crops also contend with whitefly infestations. Available information suggests the culprit in all cases to be strain $B$, which is now recognized as a separate species called Bemisia argentifolii.

B. argentifolii, or silverleaf whitefly, was classified as a separate species from $B$. tabaci, sweetpotato whitefly, based on the following criteria: (1) reproductive isolation from $B$. tabaci, meaning they do not mate with each other, and (2) genetic variation as characterized by biochemical assays of allozymes (Perring et al. 1993). The case for basic biological differences between the two types of whiteflies is supported by the fact that silverleaf whitefly infects more types of crops than sweetpotato whitefly, and that there are apparent differences in virus transmission specificities. The two types of whiteflies transmit different viruses. In addition, Bellows et al. (1994) identified subtle morphological differences between the types such as the absence of dorsal seta, the width of the thoracic tracheal folds and the width of the wax extrusions from the tracheal folds in the fourth nymphal instar.

Although the debate continues over whether the differences between the two whiteflies indeed warrant sepa- rate species status, the facts are clear concerning the greater pest potential of the silverleaf whitefly compared to the sweetpotato whitefly. The silverleaf whitefly colonizes more crop hosts and causes various toxicogenic disorders on many of them (Bethke et al. 1991). For example, silverleaf whitefly causes irregular ripening in tomatoes, white stalk in broccoli and silverleaf in cucurbits, whereas the sweetpotato whitefly causes none of these. Besides being more widespread, the silverleaf whitefly is more difficult to control because it can lay more eggs and so can increase faster, colonizes the undersides of leaves, which are difficult to reach with pesticides, and has a tremendous ability to disperse from declining or perturbed habitats such as cut alfalfa (Yee at al. 1997). Although potent new insecticides for whitefly control have been introduced since 1991, population densities have remained at economically damaging levels in California each year.

\section{Outbreaks in California}

Whitefly infestations in California can be divided into two eras: the pre1990 sweetpotato whitefly infestations and the post-1990 silverleaf whitefly infestations. Before 1990, sweetpotato whitefly occurred primarily as a cotton pest, building to moderate densities in many cotton fields in the Imperial Valley during July and August. The most spectacular exception was the 1981 outbreak, when sweetpotato whitefly infestations grew beyond the capacity of cotton fields and spilled over into fall vegetables. Usually, however, whiteflies threatened noncotton crops by spreading viruses in fall-planted lettuce and melons rather than by damaging them directly. Consequently, almost all whitefly management efforts were targeted to cotton only.

Then in 1990, whiteflies infested melons, which was unusual, as well as various cole crops such as broccoli, cauliflower and cabbage, which had never happened before in Southern California. In retrospect, these were the first indications of silverleaf white- 
fly invasions in California (although it is possible that undetected infiltration may have been occurring even earlier than 1990). In the summer and fall of 1991, it became clear that there had been a significant shift in whitefly pest potential: whitefly populations exploded to unmanageable levels, infesting and multiplying on virtually every crop in California. The post-1990 silverleaf whitefly infestations have required extensive management inputs into spring melons and squash, summer cotton and alfalfa, and fall melons, lettuce and cole crops. These include monitoring for insecticide resistance, monitoring populations for treatment decisions, dispersal, early termination or harvest of crops, and so on.

The greater capacity of the silverleaf whitefly to colonize various crops, weeds, ornamentals and citrus has produced higher population densities of whiteflies that are sustained for longer periods through the annual crop cycle (fig. 1). Proximity of diverse crops to one another in overlapping crop development stages ensures a large, stable resource base that the silverleaf whitefly exploits maximally. The whitefly's well-developed ability to disperse from declining crops to those in an earlier developmental stage helps in avoiding population crashes. This is perhaps a central issue for an organism that lacks an adaptive resting stage and must therefore always be closely associated with its plant hosts. As long as a sequence of hosts are present in abundance, chances are that silverleaf whitefly populations will also be present.

\section{Factors contributing to outbreaks}

The level of infestation of crops attained by colonizing pests such as the silverleaf whitefly depends on: (1) biological factors: those trâits of an organism which, under environmental influence, characterize its intrinsic potential to utilize a given resource; (2) agricultural factors: the crops grown, relative acreages, spatial and temporal proximity to one another, etc.; and (3) management factors: the efficacy of chemical, biological and cultural controls.

\section{Biological factors}

While the sweetpotato and silverleaf whiteflies are similar in many basic traits, the silverleaf whitefly is exceptional in its ability to colonize a wide range of crops, weeds and ornamentals (Perring et al. 1991, Blua et al. 1995). The apparently greater host range of the silverleaf whitefly may be partly due to higher population densities which "force" colonization of marginal hosts as a spillover effect. This is not to minimize the very real capacity of the silverleaf whitefly to multiply on so many commercial crops that its population remains high throughout the annual growing season (Yee \& Toscano 1996, Yee et al. 1997).

In addition, studies suggest that silverleaf whitefly populations increase faster than sweetpotato whitefly populations. On cotton, female silverleaf whiteflies lay about 85 eggs in 24 hours, while female sweetpotato whiteflies lay only about 51 (Bethke et al. 1991). If silverleaf whitefly populations do increase more rapidly, they could both exploit a particular crop

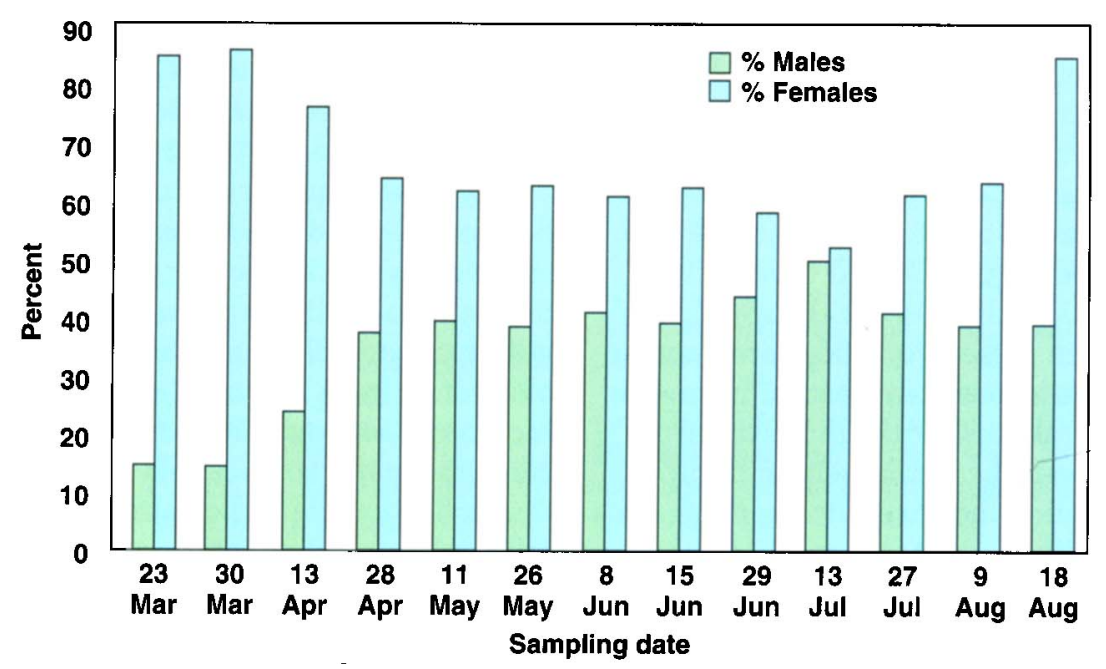

Fig. 2. Whitefly sex ratios in cotton and melons, Imperial Valley 1994.
The silverleaf whitefly is more difficult to control, colonizes more crop species and causes various disorders in many of them.

faster and outstrip the ability of natural enemies to control them. Indeed, silverleaf whitefly populations in California appear not only to increase faster than their natural enemies, but to escape predation and parasitism altogether (Gruenhagen et al. 1993, Yee et al. 1997).

A biological trait of many whitefly species including the silverleaf whitefly is the production of unequal numbers of male and female offspring. Field surveys of silverleaf whitefly populations suggest a mostly femalebiased sex ratio throughout their annual cycle (fig. 2). This could be an integral part of the reason silverleaf whiteflies have such high capacity for rapid increase. 


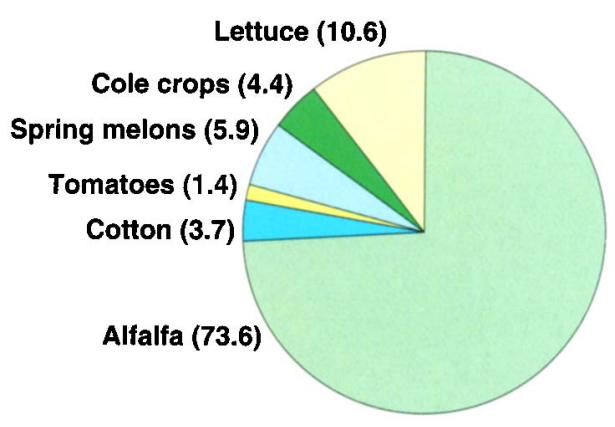

Fig. 3. Relative acreages of major whitefly crops in the Imperial Valley.

A basic biological capacity for explosive increase is meaningless in an unsuitable environment. Assuming that all crop systems are equal, silverleaf whitefly populations would likely grow the most in environments similar to the Imperial Valley, where daily temperatures exceed $100^{\circ} \mathrm{F}$ during the 3 to 4 months of the year that silverleaf whitefly populations increase most rapidly. In the San Joaquin Valley, 300 miles to the north of the Imperial Valley, silverleaf whitefly populations occur on similar crops, but with the exception of some areas of Kern and Tulare counties, rarely increase to such high levels as in the Imperial Valley. Temperatures in San Joaquin are not as high and consequently whitefly generation time is not as fast as in the Imperial Valley.

The absence of rainfall also appears to benefit whiteflies, as depression in their populations has frequently been reported following intense rainfalls or extended periods of rain. While the agriculture in Texas' Rio Grande Valley is similar to that of the Imperial Valley, five times as much rain falls in the Rio Grande Valley (15 vs. 3 inches per year) and whitefly populations there have never approached those of the Imperial Valley. While the contrasts between these two valleys are only anecdotal, a consistent pattern from year to year argues for the importance of the physical environment in rapid population increases of silverleaf whiteflies.

Dispersal is another aspect of silverleaf whitefly biology that is critical to understanding its pest potential. Movement of whitefly populations from one field to another as well as from one crop to the next enable whitefly populations to sustain high densities. Dispersal events during the hot summer months occur from sunup until 9 or 10 A.M. - beyond midmorning, temperatures become so high that whiteflies stop flying. Dispersing whiteflies that do not locate new hosts are often observed sheltered in vegetation or in moist habitats at ground level during the heat of the day. It is possible that dispersing whiteflies make incremental movements over a period of days prior to locating a suitable plant host.

\section{Agricultural factors}

The importance of the agricultural system in driving silverleaf whitefly populations to extreme densities should not be underestimated. The types and sequences of crops grown in the Imperial Valley provide a lush, stable resource for whitefly populations. The spring melon crop is planted from January to March, when silverleaf whitefly populations are at their lowest point due to the cooler winter temperatures. The whitefly numbers are so low that movement into melon fields from surrounding winter annual weeds, late-season cole crops and ornamentals is barely detectable. As the spring temperatures increase, however, silverleaf whiteflies begin to increase on the fast-growing melon vines. By the time melons are harvested from May to July, whitefly populations in Southern California are 1,000 times higher.

Dry-down and harvest of the melon fields send clouds of dispersing adult silverleaf whiteflies to all corners of the Imperial Valley, where they infest young cotton fields and vast acreages of alfalfa (fig. 3). During the summer months cotton and alfalfa fields become the major sources of whitefly multiplication. Periodic cuttings of alfalfa fields and defoliation and harvest of cotton in August and September send more swarms of dispersing whiteflies into young fields of lettuce and cole crops. As a result, from June through October there is a perpetual swarm of whiteflies immigrating into crops, forcing heavy reliance upon insecticides. For example, fall melons can no longer be grown in the Imperial Valley without preventive insecticide treatments due to the extreme whitefly pressure at this time of year.

The Coachella Valley, which lies 60 miles north of the Imperial Valley, has an identical climate and is also an intensively farmed, irrigated desert valley. The predominant crops grown in the Coachella Valley are dates, citrus and grapes, which do not sustain populations of whiteflies. There are only limited acreages of melons and alfalfa, and there is no cotton. Consequently, the vast resource base for exploitation by silverleaf whitefly does not exist, and only small to moderate populations of whiteflies occur. These are easily managed with insecticide applications because there is no constant pool of dispersing whiteflies to immigrate back into treated fields.

Melons are probably one of the agricultural factors that increased the explosive potential of the silverleaf whitefly in the Imperial Valley and Kern County. In many irrigated regions of Arizona where few crops other than cotton are grown, whitefly populations are smaller, build up more gradually and do not disperse explosively.

Management of building whitefly populations in Arizona by coordinating the crops grown allows for timely treatments of insecticides to maintain the population below damaging levels. These regions also have periods through late fall-winter months in which no crops are grown, a practice that helps drive whitefly numbers down to low levels. In contrast, the crops grown year-round in Southern California help to sustain whiteflies.

\section{Management factors}

Beginning in 1991, silverleaf whitefly populations have remained at extreme levels throughout much of the southwestern United States, necessitating intensive insecticide use to pro- 
tect crops. Some pyrethroid and organophosphate insecticides are losing their effectiveness for controlling whiteflies below crop-damaging levels. High levels of resistance to many pyrethroids and organophosphates have been reported in whitefly field populations in various regions including the San Joaquin Valley, Palo Verde Valley, Israel and Sudan (Prabhaker et al. 1985, Dittrich et al. 1985, Horowitz et al. 1988) and more recently in Pakistan (Cahill et al. 1995). Over the past 5 years in the Imperial Valley, there have been no strong trends of whitefly resistance to the insecticides bifenthrin (Capture), endosulfan (Thiodan) and chlorpyrifos (Lorsban). Conceivably, the lack of significant insecticide resistance in the Imperial Valley is due in part to a large reservoir of susceptible populations maintained in untreated crops (such as alfalfa, whose shortened cutting cycles keep populations below damaging levels). Susceptible insects disperse into treated fields, diluting resistant populations.

However, there are indications that insecticide resistance is building in whiteflies in the Palo Verde and San Joaquin valleys (Prabhaker et al. 1996). A study of whitefly resistance in the Palo Verde Valley in August 1993 showed that it took 33.8 times as much bifenthrin and 36 times as much endosulfan to kill half of the Palo Verde adults as it did to kill half of the adults in a laboratory population that had not previously been exposed to pesticides. Similarly, before 1997 in the San Joaquin Valley counties of Kern and Tulare, bifenthrin and chlorpyrifos killed all of the whiteflies in insecticide-coated yellow sticky card tests for monitoring whitefly insecticide resistance, which were developed by Prabhaker et al. (1992) and reported by Castle et al. (1996). However, in 1997, yellow sticky card tests showed that bifenthrin and chlorpyrifos applied at the rates recommended on the labels killed only $35 \%$ to $92 \%$ and $30 \%$ to $87 \%$ of the whiteflies, respectively.

Due to the whitefly's increasing resistance to pesticides, research into biological control agents is being pursued. Many releases of exotic natural whitefly enemies - such as Eretmocerus species - have been made in the past 2 years in California's agricultural system. Researchers need more time to obtain information on whether these parasitoids are established, as well as the impact they will have upon whitefly populations. It will likely take more than 3 years before we will see any impact from these natural-enemy introductions. One problem is the seasonality of many natural-enemy populations, which are not well developed at the time whiteflies are beginning to increase in late spring. It is also uncertain whether these natural enemies are adept enough at dispersal to follow whiteflies from crop to crop. In addition, the current use of broad spectrum insecticides in the agricultural system is a major obstacle to establishing whitefly natural enemies in the field. Whitefly pest management programs need to allow native and exotic natural enemies to operate by reducing insecticide use and registering relatively selective compounds such as imidacloprid (Admire), buprofezin (Applaud) and pyriproxyfen (Knack).

N.C. Toscano is Extension Entomologist, Department of Entomology, UC Riverside; S.J. Castle is Research Entomologist, and T.J. Henneberry is Laboratory Director, USDA-ARS, Western Cotton Research Laboratory, Phoenix, $A Z$; and $N$. Prabhaker Castle is Postdoctoral Researcher, Department of Entomology, UC Riverside.

\section{References}

Bellows TS, Perring TM, Gill RJ, Headrick DH. 1994. Description of a species of Bemisia (Homoptera: Aleyrodidae). Ann Entomol Soc Am 87: 195-206.

Bethke JA, Paine TD, Nuessley GS 1991. Comparative biology, morphometrics, and development of two populations of Bemisia tabaci (Homoptera: Aleyrodidae) on cotton and poinsettia. Ann Entomol Soc Am 84(4): 407-11.

Blua MJ, Perring TM, Nuessley GS, Duffus JE, Toscano NC. 1994. Seasonal cropping pattern effects on abundance of Bemisia tabaci (Homoptera: Aleyrodidae) and incidence of lettuce infectious yellow virus. Environ Entomol 23: 1422-27.

Blua MJ, Yoshida HA, Toscano NC. 1995. Oviposition preference of two Bemisia species (Homoptera: Aleyrodidae). Environ Entomol 24: 88-93.

Brown JK. 1994. Current status of Bemisia tabaci as a plant pest and virus vector in agroecosystems worldwide. FAO Plant Prot Bull 42: 3-3 2.

Cahill M, Byrne FJ, Gorman K, Denholm I, Devonshire AL. 1995. Pyrethroid and organophosphate resistance in the tobacco whitefly Bemisia tabaci (Homoptera: Aleyrodidae). Bull Ent Res 85: 181-187.

Castle SJ, Henneberry TJ, Toscano NC, Prabhaker N, Birdsall S, Weddle D. 1996. Silverleaf whiteflies show no increase in insecticide resistance. Cal Ag 50(1): 18-23.

Dittrich V, Hassan SO, Ernst GH. 1985. Sudanese cotton and the whitefly: a case study of the emergence of a new primary pest. Crop Protect 4: 161-76.

Gruenhagen NM, Perring TM, Bezark LG, Daoud DM, Leigh TF. 1993. Silverleaf whitefly present in the San Joaquin Valley. Cal Ag 47(1):4-6

Horowitz AR, Toscano NC, Youngman RR, Georghiou GP. 1988. Synergism of insecticides with DEF in sweetpotato whitefly (Homoptera: Aleyrodidae). J Econ Entomol 81: 110-4.

Perring TM, Cooper A, Kazmer DJ, Shields C, Shields J. 1991. New strain of sweetpotato whitefly invades California veg etables. Cal Ag 45: 10-12.

Perring TM, Cooper AD, Rodriguez RJ, Farrar CA, Bellows TS. 1993. Identification of a whitefly species by genomic and behavioral studies. Science 259: 74-7.

Prabhaker N, Coudriet DL, Meyerdirk DE. 1985. Insecticide resistance in the sweetpotato whitefly, Bemisia tabaci (Homptera: Aleyrodidae). J Econ Entomol 78: 748-52.

Prabhaker N, Toscano NC, Perring TM, Nuessley G, Kido K, Youngman RR. 1992. Resistance monitoring of the sweetpotato whitefly (Homoptera: Aleyrodidae) in the Imperial Valley of California. J Econ Entomol 85: 1063-8.

Prabhaker N, Toscano NC, Henneberry TJ, Castle SJ, Weddie D. 1996. Assessment of two bioassay techniques for resistance monitoring of silverleaf whitefly (Homoptera: Aleyrodidae) in California. J Econ Entomol 89: 805-15.

Yee WL, Toscano NC. 1996. Ovipositional preference and development of Bemisia argentifolii (Homoptera:

Aleyrodidae) in relation to alfalfa. $J$ Econ Entomol 89: 870-6.

Yee WL, Toscano NC, Palumbo JC, Blua MJ, Yoshida HA. 1997. Seasonal population trends of Bemisia argentifolii (Homoptera: Aleyrodidae) on alfalfa in southern California and Arizona. Environ Entomol 26: 241-9. 